\title{
Acute effect of L-796568, a novel beta 3-adrenergic receptor agonist, on energy expenditure in obese men
}

Citation for published version (APA):

van Baak, M. A., Hul, G. B. J., Toubro, S., Astrup, A., Gottesdiener, K. M., de Smet, M., \& Saris, W. H. M. (2002). Acute effect of L-796568, a novel beta 3-adrenergic receptor agonist, on energy expenditure in obese men. Clinical Pharmacology \& Therapeutics, 71(4), 272-279.

https://doi.org/10.1067/mcp.2002.122527

Document status and date:

Published: 01/01/2002

DOI:

10.1067/mcp.2002.122527

Document Version:

Publisher's PDF, also known as Version of record

\section{Please check the document version of this publication:}

- A submitted manuscript is the version of the article upon submission and before peer-review. There can be important differences between the submitted version and the official published version of record.

People interested in the research are advised to contact the author for the final version of the publication, or visit the DOI to the publisher's website.

- The final author version and the galley proof are versions of the publication after peer review.

- The final published version features the final layout of the paper including the volume, issue and page numbers.

Link to publication

\footnotetext{
General rights rights.

- You may freely distribute the URL identifying the publication in the public portal. please follow below link for the End User Agreement:

www.umlib.nl/taverne-license

Take down policy

If you believe that this document breaches copyright please contact us at:

repository@maastrichtuniversity.nl

providing details and we will investigate your claim.
}

Copyright and moral rights for the publications made accessible in the public portal are retained by the authors and/or other copyright owners and it is a condition of accessing publications that users recognise and abide by the legal requirements associated with these

- Users may download and print one copy of any publication from the public portal for the purpose of private study or research.

- You may not further distribute the material or use it for any profit-making activity or commercial gain

If the publication is distributed under the terms of Article $25 \mathrm{fa}$ of the Dutch Copyright Act, indicated by the "Taverne" license above, 


\title{
Acute effect of L-796568, a novel $\beta_{3}$-adrenergic receptor agonist, on energy expenditure in obese men
}

\begin{abstract}
Objective: Our objective was to investigate the thermogenic efficacy of single oral doses of the novel $\beta_{3^{-}}$ adrenergic receptor agonist L-796568 [(R)- $N$-[4-[2-[[2-hydroxy-2-(3-pyridinyl)ethyl]amino]ethyl]phenyl]-4-[4-[4-(trifluoromethyl)phenyl]thiazol-2-yl]-benzenesulfonamide, dihydrochloride] in humans.

Methods: Twelve healthy overweight to obese men participated in this 2-center, 3-period, randomized, placebo-controlled, crossover trial. In each period subjects received $250 \mathrm{mg} \mathrm{L}-796568,1000 \mathrm{mg} \mathrm{L}-796568$, or placebo. Energy expenditure and respiratory quotient were determined by indirect calorimetry; blood samples were taken; and ear temperature, heart rate, and blood pressure were measured at baseline and during the 4-hour period after administration.

Results: Energy expenditure increased significantly after the $1000-\mathrm{mg}$ dose (about $8 \%$ ) and this was accompanied by an increase in plasma glycerol and free fatty acid concentrations. Systolic blood pressure also increased significantly. No changes in heart rate, diastolic blood pressure, ear temperature, plasma catecholamine, potassium, or leptin were found.

Conclusions: Single-dose administration of $1000 \mathrm{mg}$ of the novel $\beta_{3}$-adrenergic receptor agonist L-796568 increased lipolysis and energy expenditure in overweight men. This is the first study to show such an effect of $\beta_{3}$-adrenergic receptor agonists in humans without significant evidence for $\beta_{2}$-adrenergic receptor involvement. (Clin Pharmacol Ther 2002;71:272-9.)
\end{abstract}

Marleen A. van Baak, PhD, Gabby B. J. Hul, MSc, Søren Toubro, PhD, Arne Astrup, MD, PhD, Keith M. Gottesdiener, MD, Marina DeSmet, PharmD, PhD, and Wim H. M. Saris, MD, PhD Maastricht, The Netherlands, Copenhagen, Denmark, and Rahway, NJ

The prevalence of obesity is increasing in many countries all over the world. ${ }^{1}$ The health risks associated with obesity, such as type 2 diabetes, hypertension, coronary artery disease, gallbladder disease, and arthritis, form a serious public health problem for the years to come if no effective strategies to prevent and treat it

From the Nutrition and Toxicology Research Institute (NUTRIM), Department of Human Biology, Maastricht University; the Research Department of Human Nutrition, Royal Veterinary and Agricultural University, Copenhagen; and Merck \& Co, Inc, Rahway.

Supported by Merck \& Co, Inc, Rahway, NJ.

Received for publication July 19, 2001; accepted Dec 29, 2001.

Reprint requests: Marleen A. van Baak, PhD, Department of Human Biology, Maastricht University, PO Box 616, 6200 MD Maastricht, The Netherlands.

E-mail:m.vanbaak@hb.unimaas.nl

Copyright $(\odot 2002$ by the American Society for Clinical Pharmacology and Therapeutics.

$0009-9236 / 2002 / \$ 35.00+0 \quad \mathbf{1 3 / 1 / 1 2 2 5 2 7}$

doi:10.1067/mcp.2002.122527 are developed. ${ }^{1}$ Comprehensive weight management programs, including a reduction of energy intake through an energy-restricted diet and an increase in energy expenditure through increased levels of physical activity in combination with a behavior modification program, have been developed. In many cases such programs lead to considerable short-term weight loss. However, long-term maintenance of the reduced weight often fails to occur. Current pharmacologic approaches to the treatment of obesity focus on reinforcement of these programs and they have been shown to improve long-term weight maintenance success. ${ }^{2,3}$ The pharmacologic agents currently available for the management of obesity (orlistat and sibutramine) are effective through decreased nutrient absorption and appetite suppression, respectively. The approach of increased energy expenditure has been less well explored.

The peripheral sympathetic nervous system plays an important role in the regulation of energy expenditure. ${ }^{4}$ Stimulation of sympathetic activity results in an 
increase of resting energy expenditure in humans, which is mediated by $\beta$-adrenergic receptors. ${ }^{5}$ Both $\beta_{1^{-}}$ and $\beta_{2}$-adrenergic receptors lead to thermogenesis on stimulation. 6,7 Obesity appears to be associated with a blunted response to sympathetic stimulation that is probably caused mainly by $\beta_{2}$-adrenergic receptor malfunction. ${ }^{7,8}$ However, treatment of obesity with the classic nonselective or $\beta_{2}$-selective agonists is not possible, because of the many unacceptable side effects of these drugs.

The discovery of a third $\beta$-adrenergic receptor subtype in humans, which in animal models has been shown to stimulate lipolysis in brown and white adipose tissue and lead to thermogenesis in brown adipocytes, has opened new possibilities for treatment of human obesity by selective $\beta_{3}$-adrenergic receptor stimulation. In humans the presence of $\beta_{3}$-adrenergic receptor mRNA has been shown in brown and white adipose tissue and the gall bladder, colon, stomach, small intestine, prostate gland, and heart but not in skeletal muscle or the liver, lung, kidney, thyroid, or lymphocytes. ${ }^{9-12}$ One study has more recently provided evidence for the presence of the $\beta_{3}$-adrenergic receptor protein in human gastrocnemius muscle and the right atrium. ${ }^{13}$ Although most of the currently available $\beta_{3^{-}}$ adrenergic receptor agonists are only weak partial agonists of the human $\beta_{3}$-adrenergic receptor and usually not very selective, a functional role for the $\beta_{3}$-receptor in adipocyte lipolysis has been suggested by studies in isolated human omental and subcutaneous fat cells ${ }^{14,15}$ and in vivo in microdialysis studies with such agonists. ${ }^{16-18}$ Because these drugs are not available for intravenous or oral administration in humans, their thermogenic efficacy is unknown. Indirect studies that used combinations of different sympathomimetics and blockers to dissect out the contribution of the $\beta_{3}$-receptor to human thermogenesis have yielded inconsistent results. ${ }^{19-22}$

L-796568 [(R)- $N$-[4-[2-[[2-hydroxy-2-(3-pyridinyl) ethyl]amino]ethyl]-phenyl]-4-[4-[4-(trifluoromethyl)phenyl]thiazol-2-yl]-benzenesulfonamide, dihydrochloride] is a newly developed $\beta_{3}$-adrenergic receptor agonist with high affinity (concentration that produces $50 \%$ of the maximum possible response $\left.\left[\mathrm{EC}_{50}\right], 3.6 \pm 2.2 \mathrm{nmol} / \mathrm{L}\right)$ and efficacy $(94 \% \pm 10 \%$ of maximal cyclic adenosine monophosphate accumulation by isoproterenol [INN, isoprenaline]) for the cloned human $\beta_{3}$-adrenergic receptor transfected in Chinese hamster ovary cells. ${ }^{23} \mathrm{~L}-796568$ is a weak partial agonist at the human $\beta_{1}$-receptor and $\beta_{2}$-receptor, with $\mathrm{EC}_{50}$ values of 4.8 and $2.4 \mu \mathrm{mol} / \mathrm{L}$, respectively, and efficacy of $25 \%$ of isoproterenol activity. ${ }^{23}$ Phase I human studies showed that L-796568 was well tolerated in doses up to $1500 \mathrm{mg}$. Administration of L796568 therefore allows us to study, for the first time, the effects of a specific human $\beta_{3}$-adrenergic receptor agonist on in vivo lipolysis and thermogenesis in humans. This study was designed to investigate the thermogenic efficacy of single oral doses of 250 and $1000 \mathrm{mg} \mathrm{L}-796568$ in obese men.

\section{METHODS}

Subjects. Twelve healthy, nonsmoking male volunteers between 18 and 45 years old (mean \pm SD, $34.4 \pm 5.8$ years) were included in the study. All of the subjects had maintained a stable weight $( \pm 4 \mathrm{~kg})$ and had a body mass index between 28 and $34 \mathrm{~kg} / \mathrm{m}^{2}$ (mean $\pm \mathrm{SD}, 30.7 \pm 2.1$ $\mathrm{kg} / \mathrm{m}^{2}$ ). None of the volunteers had participated in an organized weight loss program during the previous 3 months. All had normal blood pressure measurements ( 90 to $150 \mathrm{~mm} \mathrm{Hg}$ systolic and 50 to $95 \mathrm{~mm} \mathrm{Hg}$ diastolic blood pressure) and resting heart rates ( $<90$ beats/min). Habitual heavy consumers of coffee ( $>4$ cups per day) were excluded. Current or anticipated use of any prescription or nonprescription drugs was not allowed.

Experimental protocol. The study was a 2-center, 3-period, randomized, placebo-controlled, crossover trial. In each period subjects received $250 \mathrm{mg}$ L796568, $1000 \mathrm{mg} \mathrm{L}-796568$, or placebo in a balanced fashion. All drug supplies were provided as a "double dummy," so investigators and subjects were blinded to the treatment regimen. A washout period of 6 to 8 days between study periods allowed plasma levels of L796568 to dissipate. Prestudy procedures included a medical history and a physical examination that included vital signs, determination of body mass index, measurement of thyroid function parameters, a safety laboratory panel for blood and urine, and a 12-lead electrocardiogram (ECG).

On the test days the subjects came to the laboratory in the morning after an overnight fast. Urine was collected for the safety panel. Subjects rested in a semirecumbent position, and a catheter was inserted into a forearm vein of each subject for blood sampling (100 minutes before dosing). Continuous heart rate and blood pressure monitoring was started, and heart rate and blood pressure were registered at 65 and 20 minutes before dosing. At 10 minutes before dosing, blood samples were taken for plasma catecholamine concentration (heparinized tubes that contained glutathione), plasma free fatty acids and glycerol concentration (ethylenediaminetetra-acetic acid tubes), plasma potassium (lithium-heparin tubes), and serum leptin concentration (serum tubes), as well as for the safety laboratory panel. 
At 0 minutes before dosing, another blood sample was obtained for free fatty acids and glycerol concentration and for serum leptin concentration. After all blood was drawn, the catheter was flushed with saline solution. Ear temperature was determined at 60 minutes before dosing. Energy expenditure was measured for $30 \mathrm{~min}-$ utes, from 60 minutes before dosing to 30 minutes before dosing, as a predose baseline.

After the baseline measurements, each subject was given a single oral dose of the study drug ( $250 \mathrm{mg}$ or $1000 \mathrm{mg} \mathrm{L}-796568$ or placebo) with $240 \mathrm{ml}$ water and continued to fast and rest in a semisupine position for 4 hours. During this period, energy expenditure was measured during the last 20 minutes of each half hour. The first 10 minutes of each half hour was used for either blood sampling or calibration or both. Blood pressure and heart rate continued to be monitored and were recorded every 30 minutes. Blood samples for potassium, free fatty acids, and glycerol were obtained at 1, 2, 3, and 4 hours after dosing. Blood samples were obtained 1.5 and 4 hours after dosing for plasma catecholamines and 4 hours after dosing for leptin. The catheter was flushed with saline solution after each blood sample was drawn. Four hours after dosing, ear temperature was measured and a 12-lead ECG was obtained.

Methods. Energy expenditure was determined by indirect calorimetry with use of a ventilated hood system. Flow through the hood was set at approximately $50 \mathrm{~L} / \mathrm{min}$ and was measured with a dry gas meter (Maastricht: Schlumberger, Dordrecht, The Netherlands; Copenhagen: Oxycon-beta, Mijnhardt, The Netherlands). $\mathrm{VO}_{2}$ and $\mathrm{VCO}_{2}$ were determined every 15 seconds from flow through the hood and the difference in oxygen (Maastricht: paramagnetic oxygen analyzer, Servomex, Crowborough, United Kingdom; Copenhagen: Oxycon-beta) and carbon dioxide (Maastricht: paramagnetic $\mathrm{CO}_{2}$ analyzer, Servomex; Copenhagen: Oxycon-beta) concentrations between ingoing and outgoing air. Identical calibration procedures were used in the two centers. Respiratory quotient was calculated as $\mathrm{V}_{\mathrm{CO}_{2}} / \mathrm{VO}_{2}$. Energy expenditure was calculated from $\mathrm{YO}_{2}$ and $\mathrm{VCO}_{2}$ with the abbreviated Weir formula. ${ }^{24}$

Blood pressure and heart rate were measured with a semiautomated device (Maastricht: Omron 705 CP, Hamburg, Germany; Copenhagen: digital blood pressure meter model UA-743, A \& D Company, Tokyo, Japan). Heart rate monitoring was performed by means of a 3-lead ECG monitor (Maastricht: Cardiolife, Nikon-Kohden, Tokyo, Japan; Copenhagen: Diascope 2, model 211, Simonsen \& Weel, Copenhagen, Denmark). The 12-lead ECG was registered by means of a Cardiette Daedalus View H, H\&C Medical Devices,
Cavareno, Italy (Maastricht), or a Microsmart MC, Marquette Hellige, Freiburg, Germany (Copenhagen).

Analytic methods. Blood for serum leptin was allowed to clot at least 30 minutes and was then centrifuged for 15 minutes at $1200 \mathrm{~g}$ at room temperature. All other blood samples were centrifuged immediately at $4^{\circ} \mathrm{C}$ for 15 minutes at $1200 \mathrm{~g}$ except for the sample for potassium, which was centrifuged at room temperature. Plasma and serum were stored at $-80^{\circ} \mathrm{C}$ until analysis.

Plasma free fatty acids, ${ }^{25}$ glycerol, ${ }^{26}$ potassium (direct potentiometry with an ion-selective electrode), and serum leptin $^{27}$ were analyzed at the Department of Clinical Chemistry, Academic Hospital of the Free University of Brussels (Brussels, Belgium). Plasma catecholamine concentrations (norepinephrine and epinephrine) were analyzed at the Department of Human Biology in Maastricht by HPLC with electrochemical detection by use of a kit from Recipe (München, Germany). ${ }^{28}$

Data analysis. Data are presented as mean values \pm $\mathrm{SD}$, unless stated otherwise. For all variables, mean values at baseline (ie, predose for each treatment period) and at 4 hours after dosing were calculated. Within-treatment changes from baseline to 4 hours after dosing were computed by subtracting the baseline value from the 4-hour postdose value $[\Delta 4-0 \mathrm{~h}]$ ). In addition, mean energy expenditure during the 4-hour postdose period (mean 0-4 h) and 1-hour peak values were calculated for energy expenditure (for each treatment the two 20-minute measurements within each hour were averaged and the highest 1hour mean value was chosen as the 1-hour peak value). The 3 treatments were compared by ANOVA for repeated measures (baseline values, 4-hour postdose values, and changes over the 4-hour postdose period [ $\Delta 4-0 \mathrm{~h}])$. In case of a significant overall ANOVA outcome $(P<.050)$, post hoc comparisons between the 250- and 1000-mg doses of L-796568 and placebo were performed by paired $t$ tests. Within-treatment differences between the 4-hour postdose and baseline measurements were analyzed by paired $t$ tests. A $P$ value $<.050$ was considered to be statistically significant.

\section{RESULTS}

L-796568 was generally well tolerated in this study. Side effects were reported by 7 subjects, were of mild to moderate intensity, and had disappeared within 24 hours. No tremor was reported. No significant changes in safety laboratory parameters or urine composition were found in any subjects during the course of the study, except in 1 subject in whom low total cholesterol was found that appeared to be unrelated to the drug. At baseline there were no statistically significant differences for any of the variables among conditions. 
Table I. Values of all variables (mean \pm SD) at baseline $(0 \mathrm{~h})$ and at 4 hours after dosing $(4 \mathrm{~h})$ and the change during the 4-hour postdose period $(\Delta 4-0 \mathrm{~h})$

\begin{tabular}{|c|c|c|c|}
\hline Variable and treatment & $O h$ & $4 h$ & $\Delta 4-0 h$ \\
\hline \multicolumn{4}{|l|}{ Energy expenditure (kJ/min) } \\
\hline Placebo & $6.05 \pm 0.55$ & $6.14 \pm 0.59$ & $0.09 \pm 0.36$ \\
\hline $250 \mathrm{mg}$ & $6.11 \pm 0.53$ & $6.16 \pm 0.48$ & $0.06 \pm 0.21$ \\
\hline $1000 \mathrm{mg}$ & $5.97 \pm 0.58$ & $6.43 \pm 0.52 * *$ & $0.46 \pm 0.31 * *$ \\
\hline ANOVA & $P=.38$ & $P<.050$ & $P<.001$ \\
\hline \multicolumn{4}{|l|}{ Ear temperature } \\
\hline Placebo & $36.6^{\circ} \mathrm{C} \pm 0.5^{\circ} \mathrm{C}$ & $36.7^{\circ} \mathrm{C} \pm 0.7^{\circ} \mathrm{C}$ & $0.13^{\circ} \mathrm{C} \pm 0.40^{\circ} \mathrm{C}$ \\
\hline $250 \mathrm{mg}$ & $36.5^{\circ} \mathrm{C} \pm 0.4^{\circ} \mathrm{C}$ & $36.7^{\circ} \mathrm{C} \pm 0.6^{\circ} \mathrm{C}$ & $0.15^{\circ} \mathrm{C} \pm 0.48^{\circ} \mathrm{C}$ \\
\hline $1000 \mathrm{mg}$ & $36.4^{\circ} \mathrm{C} \pm 0.5^{\circ} \mathrm{C}$ & $36.8^{\circ} \mathrm{C} \pm 0.5^{\circ} \mathrm{C}$ & $0.33^{\circ} \mathrm{C} \pm 0.22^{\circ} \mathrm{C}$ \\
\hline ANOVA & $P=.35$ & $P=.80$ & $P=.19$ \\
\hline \multicolumn{4}{|c|}{ Plasma free fatty acids $(\mathrm{mmol} / \mathrm{L})$} \\
\hline Placebo & $0.341 \pm 0.115$ & $0.542 \pm 0.144$ & $0.183 \pm 0.138$ \\
\hline $250 \mathrm{mg}$ & $0.303 \pm 0.123$ & $0.585 \pm 0.115$ & $0.283 \pm 0.166$ \\
\hline $1000 \mathrm{mg}$ & $0.327 \pm 0.100$ & $0.780 \pm 0.185 * *$ & $0.444 \pm 0.224 * *$ \\
\hline ANOVA & $P=.63$ & $P<.001$ & $P<.010$ \\
\hline \multicolumn{4}{|l|}{ Plasma glycerol $(\mu \mathrm{mol} / \mathrm{L})$} \\
\hline Placebo & $48.0 \pm 17.3$ & $60.8 \pm 17.9$ & $11.6 \pm 21.4$ \\
\hline $250 \mathrm{mg}$ & $41.1 \pm 9.6$ & $63.4 \pm 13.8$ & $23.1 \pm 14.8^{*}$ \\
\hline $1000 \mathrm{mg}$ & $41.4 \pm 10.1$ & $78.7 \pm 20.7 * *$ & $36.3 \pm 19.6 * *$ \\
\hline ANOVA & $P=.20$ & $P<.001$ & $P<.001$ \\
\hline \multicolumn{4}{|l|}{ Respiratory quotient } \\
\hline Placebo & $0.803 \pm 0.062$ & $0.793 \pm 0.034$ & $-0.010 \pm 0.035$ \\
\hline $250 \mathrm{mg}$ & $0.834 \pm 0.052$ & $0.796 \pm 0.027$ & $-0.038 \pm 0.034$ \\
\hline $1000 \mathrm{mg}$ & $0.818 \pm 0.040$ & $0.783 \pm 0.015$ & $-0.035 \pm 0.040$ \\
\hline ANOVA & $P=.26$ & $P=.39$ & $P=.08$ \\
\hline \multicolumn{4}{|l|}{ Plasma potassium $(\mathrm{mmol} / \mathrm{L})$} \\
\hline Placebo & $4.01 \pm 0.24$ & $3.97 \pm 0.21$ & $-0.04 \pm 0.14$ \\
\hline $250 \mathrm{mg}$ & $4.10 \pm 0.28$ & $3.87 \pm 0.14$ & $-0.23 \pm 0.24$ \\
\hline $1000 \mathrm{mg}$ & $4.18 \pm 0.59$ & $3.94 \pm 0.14$ & $-0.24 \pm 0.55$ \\
\hline ANOVA & $P=.56$ & $P=.22$ & $P=.29$ \\
\hline \multicolumn{4}{|l|}{ Heart rate (beats/min) } \\
\hline Placebo & $62.8 \pm 11.1$ & $59.4 \pm 12.5$ & $-3.5 \pm 7.1$ \\
\hline $250 \mathrm{mg}$ & $60.3 \pm 8.1$ & $62.0 \pm 7.0$ & $1.5 \pm 5.7$ \\
\hline $1000 \mathrm{mg}$ & $61.2 \pm 8.2$ & $61.4 \pm 9.0$ & $-0.2 \pm 4.4$ \\
\hline ANOVA & $P=.43$ & $P=.62$ & $P=.14$ \\
\hline \multicolumn{4}{|c|}{ Systolic blood pressure $(\mathrm{mm} \mathrm{Hg})$} \\
\hline Placebo & $128.6 \pm 6.6$ & $130.1 \pm 12.6$ & $1.1 \pm 10.0$ \\
\hline $250 \mathrm{mg}$ & $132.4 \pm 6.2$ & $135.6 \pm 12.2 *$ & $3.2 \pm 8.6$ \\
\hline $1000 \mathrm{mg}$ & $126.8 \pm 9.7$ & $139.1 \pm 13.0^{* *}$ & $12.2 \pm 14.2 * *$ \\
\hline ANOVA & $P=.16$ & $P<.050$ & $P<.010$ \\
\hline \multicolumn{4}{|c|}{ Diastolic blood pressure $(\mathrm{mm} \mathrm{Hg})$} \\
\hline Placebo & $82.9 \pm 6.7$ & $85.7 \pm 7.6$ & $2.6 \pm 5.8$ \\
\hline $250 \mathrm{mg}$ & $85.5 \pm 7.1$ & $87.3 \pm 10.0$ & $1.8 \pm 6.1$ \\
\hline $1000 \mathrm{mg}$ & $81.9 \pm 6.8$ & $88.8 \pm 10.5$ & $6.8 \pm 8.6$ \\
\hline ANOVA & $P=.12$ & $P=.29$ & $P=.13$ \\
\hline \multicolumn{4}{|c|}{ Plasma norepinephrine (ng/L) } \\
\hline Placebo & $262 \pm 70$ & $271 \pm 92$ & $9.0 \pm 54.1$ \\
\hline $250 \mathrm{mg}$ & $258 \pm 108$ & $278 \pm 113$ & $20.5 \pm 64.1$ \\
\hline $1000 \mathrm{mg}$ & $289 \pm 90$ & $324 \pm 129$ & $34.8 \pm 114.5$ \\
\hline ANOVA & $P=.29$ & $P=.16$ & $P=.69$ \\
\hline \multicolumn{4}{|l|}{ Plasma epinephine (ng/L) } \\
\hline Placebo & $28 \pm 14$ & $38 \pm 20$ & $9.8 \pm 21.0$ \\
\hline $250 \mathrm{mg}$ & $27 \pm 21$ & $32 \pm 19$ & $4.9 \pm 12.3$ \\
\hline $1000 \mathrm{mg}$ & $28 \pm 14$ & $30 \pm 14$ & $2.2 \pm 17.9$ \\
\hline ANOVA & $P=.97$ & $P=.21$ & $P=.43$ \\
\hline \multicolumn{4}{|l|}{ Serum leptin $(\mu \mathrm{g} / \mathrm{L})$} \\
\hline Placebo & $12.6 \pm 7.6$ & $11.8 \pm 6.7$ & $-0.78 \pm 1.61$ \\
\hline $250 \mathrm{mg}$ & $14.0 \pm 7.4$ & $12.8 \pm 6.6$ & $-1.18 \pm 1.17$ \\
\hline $1000 \mathrm{mg}$ & $11.9 \pm 6.7$ & $11.0 \pm 6.9$ & $-0.87 \pm 0.54$ \\
\hline ANOVA & $P=.18$ & $P=.10$ & $P=.70$ \\
\hline
\end{tabular}

ANOVA $P$ value refers to overall between-groups ANOVA outcome.

$* P<.05, * * P<.001$, versus placebo (post hoc paired $t$ tests). 
Thermogenic effects. The changes in energy expenditure from baseline during the 4-hour postdose period are shown in Fig 1. At 4 hours after dosing, energy expenditure was significantly different among the 3 conditions $(P<.05$, between-treatments overall ANOVA; Table I). Energy expenditure increased significantly from baseline to 4 hours after dosing (by $0.46 \pm 0.31$ $\mathrm{kJ} / \mathrm{min}, 7.8 \%)$ after the 1000 -mg dose $(P<.001$, withintreatment paired $t$ test). No statistically significant changes were found after the 250-mg dose $(0.06 \pm 0.21$ $\mathrm{kJ} / \mathrm{min}, 1.0 \% ; P=.35$, within-treatment paired $t$ test) or after placebo $(0.09 \pm 0.36 \mathrm{~kJ} / \mathrm{min}, 1.5 \% ; P=.41$, withintreatment paired $t$ test). The changes differed significantly among the 3 conditions $(P<.001$, between-treatments overall ANOVA; $P<.001$ for $1000 \mathrm{mg}$ versus placebo; $P=.67$ for $250 \mathrm{mg}$ versus placebo; Table I). Comparison of the 1-hour peak energy expenditures or mean energy expenditure during the period from baseline to 4 hours after dosing among the 3 treatments did not yield statistically significant differences $(P=.32$ for $1000 \mathrm{mg}$ versus placebo; $P=.88$ for $250 \mathrm{mg}$ versus placebo; between-treatments overall ANOVA).

Ear temperature values at different time points are shown in Table I. No statistically significant differences were found at any time point, and the 4-hour postdose changes did not differ among treatments $(P=.19$, between-treatments overall ANOVA).

Metabolic effects. The plasma concentrations of free fatty acids and glycerol showed a dose-dependent increase during the 4-hour postdose period (Fig 2), which differed statistically significantly among conditions $(P<.010$ for $\Delta 4-0 \mathrm{~h}$, between-treatments overall ANOVA). The changes after the $250-\mathrm{mg}$ dose $(0.283 \pm$ $0.166 \mathrm{mmol} / \mathrm{L}$ for $\Delta 4-0 \mathrm{~h}$ free fatty acids; $23 \pm 15$ $\mu \mathrm{mol} / \mathrm{L}$ for $\Delta 4-0 \mathrm{~h}$ glycerol) and after the $1000-\mathrm{mg}$ dose $(0.444 \pm 0.224 \mathrm{mmol} / \mathrm{L}$ for $\Delta 4-0 \mathrm{~h}$ free fatty acids; 36 $\pm 20 \mu \mathrm{mol} / \mathrm{L}$ for $\Delta 4-0 \mathrm{~h}$ glycerol) differed significantly from those after placebo $(0.183 \pm 0.138 \mathrm{mmol} / \mathrm{L}$ for $\Delta 4-0 \mathrm{~h}$ free fatty acids; $12 \pm 21 \mu \mathrm{mol} / \mathrm{L}$ for $\Delta 4-0 \mathrm{~h}$ glycerol) $(\Delta 4-0 \mathrm{~h}$ free fatty acids: $P<.010$, between-treatments overall ANOVA; $P=.09$ for $250 \mathrm{mg}$ versus placebo; $P<.005$ for $1000 \mathrm{mg}$ versus placebo; $\Delta 4-0 \mathrm{~h}$ glycerol: $P<.001$, between-treatments overall ANOVA; $P<.050$ for $250 \mathrm{mg}$ versus placebo; $P<.005$ for $1000 \mathrm{mg}$ versus placebo; Table I).

The respiratory quotient at 4 hours after dosing did not differ statistically significantly among treatments $(P=.39$, between-treatments overall ANOVA; Table I), although there was a tendency toward a reduction in the respiratory quotient after the $250-\mathrm{mg}(-0.038 \pm 0.034)$ and $1000-\mathrm{mg}(-0.035 \pm 0.040)$ doses compared with placebo $(-0.010 \pm 0.035)$, but the difference among treatments did not reach statistical significance $(\Delta 4-0$ h respiratory quotient: $P=.08$, between-treatments overall ANOVA). Plasma potassium concentrations showed no statistically significant changes during any of the treatments (Table I).

Cardiovascular effects. There were no statistically significant differences in heart rate between the 3 treatments at any time point, and the changes during the 4hour postdose period did not differ significantly. At 4 hours after dosing, there was a statistically significant difference in systolic blood pressure among treatments $(P<.050$, between-treatments overall ANOVA; Table I). The increase in systolic blood pressure during the 4-hour postdose period was $1.5 \pm 10.4 \mathrm{~mm} \mathrm{Hg}$ after placebo, $3.2 \pm 8.7 \mathrm{~mm} \mathrm{Hg}$ after $250 \mathrm{mg} \mathrm{L}-796568$, and $12.2 \pm 13.7 \mathrm{~mm} \mathrm{Hg}$ after $1000 \mathrm{mg} \mathrm{L}-796568(P<.005$, between-treatments ANOVA; $P=.41$ for $250 \mathrm{mg}$ versus placebo; $P<.010$ for $1000 \mathrm{mg}$ versus placebo; Table I). No statistically significant differences in diastolic blood pressure were observed during the study period (Table I).

Hormonal effects. No differences in plasma norepinephrine, epinephrine, or serum leptin concentrations were found among treatments during the 4-hour study period (Table I).

\section{DISCUSSION}

Despite the very clear role of $\beta_{3}$-adrenergic receptors in the regulation of energy expenditure in several animal models, their importance in human thermogenesis has not yet been convincingly shown. Several $\beta_{3^{-}}$ adrenergic receptor agonists have been tested in humans, but because of their poor selectivity and efficacy, the results so far have not been convincing. ${ }^{29-32}$ In contrast to these compounds, L-796568 is both a highly selective and a highly effective agonist of the human $\beta_{3}$-adrenergic receptor in vitro. ${ }^{23}$ This study clearly showed that L-796568 also has lipolytic and thermogenic activity in vivo after single-dose administration to obese men. At 4 hours after administration, the 1000-mg dose had increased energy expenditure by about $8 \%$. The time to peak plasma concentration of L796568 has been shown to be about 4 to 5 hours. ${ }^{33}$ In this study the plasma concentration of L-796568 therefore probably had not reached its peak in all individuals after the 4-hour period, and a further thermogenic effect by L-796568 after 4 hours is likely.

In vitro the $\mathrm{EC}_{50}$ of $\mathrm{L}-796568$ for stimulation of the human $\beta_{3}$-adrenergic receptor was $3.6 \mathrm{nmol} / \mathrm{L}$. The $\mathrm{EC}_{50}$ values of $\mathrm{L}-796568$ for human $\beta_{1}$-adrenergic receptor $(4770 \mathrm{nmol} / \mathrm{L})$ and $\beta_{2}$-adrenergic receptor stimulation $(2405 \mathrm{nmol} / \mathrm{L})$ were much higher than 


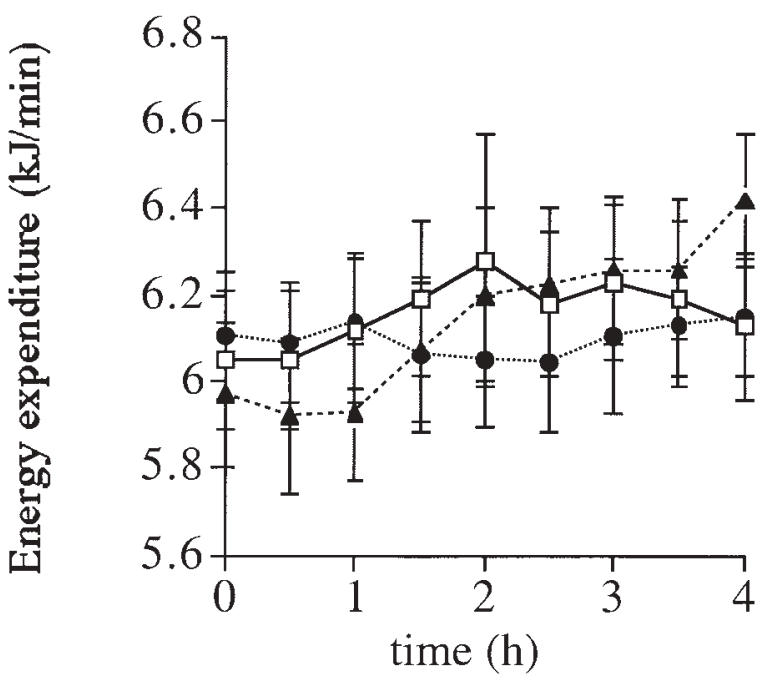

Fig 1. Energy expenditure (mean \pm SEM) after placebo

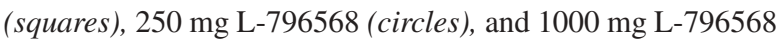
(triangles).

those for human $\beta_{3}$-adrenergic receptor stimulation. ${ }^{23}$ In another study it was found that the peak plasma concentration of L-796568 was about $28.5 \mathrm{nmol} / \mathrm{L}$ after a single $250-\mathrm{mg}$ dose and about $89.4 \mathrm{nmol} / \mathrm{L}$ after a single 1000-mg dose in lean healthy volunteers (Merck Research Laboratories. Data on file). Both concentrations were well above the $\mathrm{EC}_{50}$ of $\beta_{3}$-adrenergic receptor stimulation, and the highest concentration was still $>25$-fold lower than the $\mathrm{EC}_{50}$ for $\beta_{2}$-adrenergic receptor stimulation and $>50$-fold lower than the $\mathrm{EC}_{50}$ for $\beta_{1}$-adrenergic receptor stimulation. However, a significant contribution of $\beta_{2}$ - or $\beta_{1}$-adrenergic receptor-mediated stimulation cannot be fully excluded only on the basis of comparisons with in vitro $\mathrm{EC}_{50}$ values. Tremor and hypokalemia, indicators of $\beta_{2}$-adrenergic receptor stimulation, were not evident and it is unlikely that the effects of L-796568 were the result of stimulation of sympathetic nervous system activity because plasma catecholamine concentrations did not change.

Several in vitro studies have shown that human subcutaneous adipose tissue and especially omental adipose tissue express functional $\beta_{3}$-adrenergic receptors. ${ }^{14,15}$ Microdialysis studies have shown that these receptors are also functional in situ. ${ }^{16-18}$ This study confirms that systemic administration of a $\beta_{3}$-adrenergic receptor agonist is also capable of stimulating lipolysis in vivo. In a recent study we showed that increased plasma concentrations of free fatty acids induced thermogenesis in lean and obese subjects in the absence of stimulation by the sympathetic nervous system. ${ }^{33}$ It is
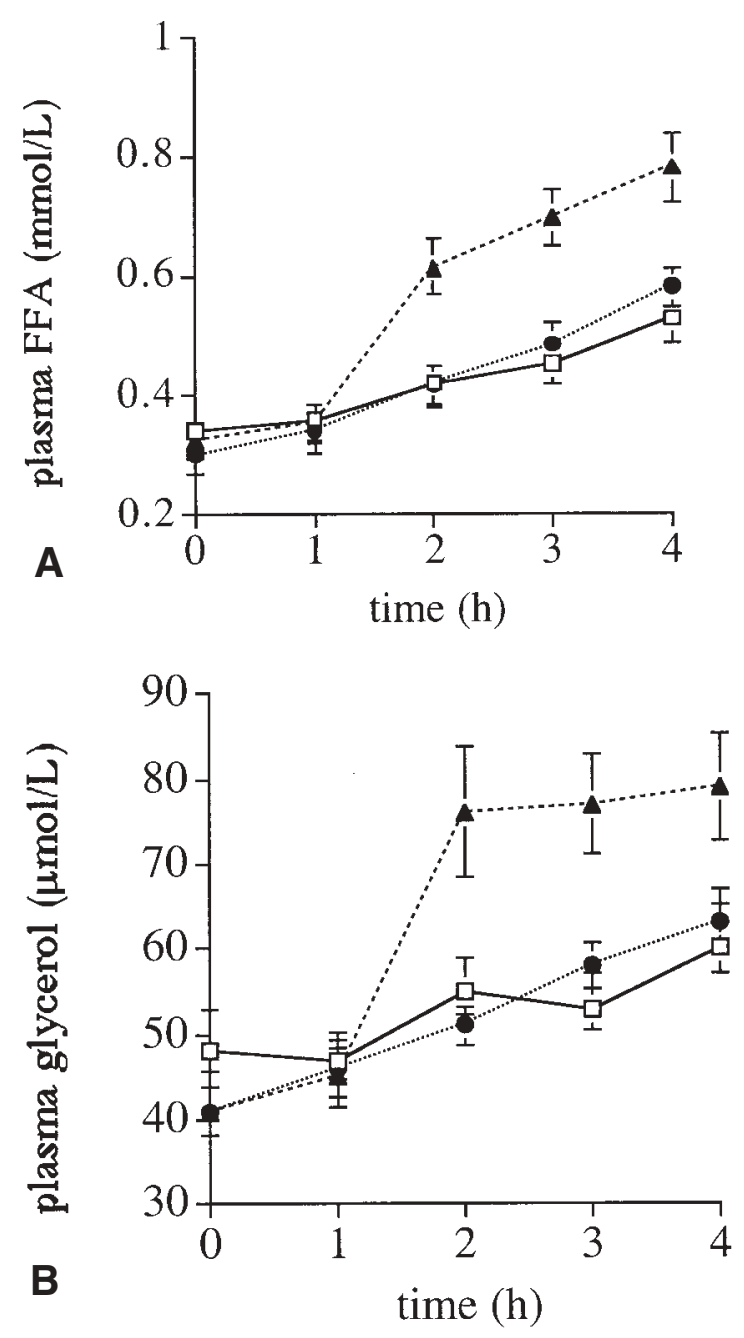

Fig 2. Mean \pm SEM plasma free fatty acid concentrations (FFA; A) and glycerol concentrations (B) after placebo

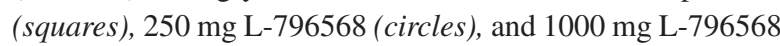
(triangles).

therefore conceivable that the thermogenic response after L-796568 administration is caused by the $\beta_{3^{-}}$ adrenergic receptor-mediated stimulation of lipolysis and does not involve any further $\beta_{3}$-adrenergic receptor-mediated effects.

Systolic blood pressure increased significantly after L-796568. In the absence of an increase in heart rate, this suggests increased contractility of the heart or an increase in total peripheral resistance. However, diastolic blood pressure did not increase significantly, which does not support an increase in peripheral resistance. Moreover, in vivo and in vitro experiments in different animal species suggest a vasodilatory effect 
of $\beta_{3}$-adrenergic agonists. ${ }^{34}$ The presence of $\beta_{3}$-adrenergic receptors in the human heart has been reported for the right atrium ${ }^{13}$ and for the ventricular endomyocardium. ${ }^{12}$ To date, the functional role of the atrial $\beta_{3^{-}}$ adrenergic receptors is unclear. Stimulation of the ventricular $\beta_{3}$-adrenergic receptors produces a negative inotropic effect in animals and in human ventricular endomyocardial biopsies. ${ }^{12,34}$ On the basis of these findings, a role for the up-regulation of $\beta_{3}$-adrenergic receptors in human heart failure as a protection against further myocyte damage has been proposed. ${ }^{34}$ However, a negative inotropic effect of stimulation of $\beta_{3^{-}}$ adrenergic receptors is not in line with the increase in systolic blood pressure that was observed in this study. On the basis of these data, an increased contractility of the heart as a result of $\beta_{1}$-adrenergic receptor stimulation by L-796568 cannot be fully excluded. However, the pattern of changes of the different variables after L796568 is not identical to that after specific $\beta_{1^{-}}\left(\right.$or $\left.\beta_{2}\right)$ adrenergic receptor stimulation. ${ }^{33}$

In conclusion, single-dose administration of $1000 \mathrm{mg}$ of the novel $\beta_{3}$-adrenergic receptor agonist L-796568 increased lipolysis and energy expenditure in overweight men. This is the first study to show such an effect of $\beta_{3}$-adrenergic receptor agonists in humans, without significant evidence for $\beta_{2}$-adrenergic receptor involvement. Involvement of $\beta_{1}$-adrenergic receptor stimulation could not be fully excluded but seems to be unlikely in view of the higher $\mathrm{EC}_{50}$ for human $\beta_{1}$ adrenergic receptor stimulation than for human SYMBOLB $_{3}$-adrenergic receptor stimulation in vitro and the plasma concentrations likely to be present.

We thank Jos Stegen for his analysis of the plasma catecholamines.

\section{References}

1. World Health Organization. Obesity: preventing and managing the global epidemic. Geneva (Switzerland): World Health Organization; 2000. WHO Technical Report Series No.: 894.

2. Sjöström L, Rissanen A, Andersen T, Boldrin M, Golay A, Koppeschaar HP, et al. Randomised placebo-controlled trial of orlistat for weight loss and prevention of weight regain in obese patients. European Multicentre Orlistat Study Group. Lancet 1998;352:167-72.

3. James WP, Astrup A, Finer N, Hilsted J, Kopelman P, Rössner $\mathrm{S}$, et al. Effect of sibutramine on weight maintenance after weight loss: a randomised trial. STORM Study Group. Sibutramine Trial of Obesity Reduction and Maintenance. Lancet 2000;356:2119-25.

4. van Baak MA. The peripheral sympathetic nervous system in human obesity. Obes Rev 2001;2:3-14.
5. Blaak EE, van Baak MA, Kempen KP, Saris WH. Role of $\alpha$-and $\beta$-adrenoceptors in sympathetically mediated thermogenesis. Am J Physiol 1993;264:E11-7.

6. Schiffelers SL, van Harmelen VJ, de Grauw HA, Saris WH, van Baak MA. Dobutamine as selective $\beta_{2}$-adrenoceptor agonist in in vivo studies on human thermogenesis and lipid utilization. J Appl Physiol 1999;87:977-81.

7. Schiffelers SL, Saris WH, Boomsma F, van Baak MA $\beta_{1}$ - and $\beta_{2}$-Adrenoceptor-mediated thermogenesis and lipid utilization in obese and lean men. J Clin Endocrinol Metabol 2001;86:2191-9.

8. Blaak EE, van Baak MA, Kemerink GJ, Pakbiers MT, Heidendal AK, Saris WH. $\beta$-Adrenergic stimulation of energy expenditure and forearm skeletal muscle metabolism in lean and obese men. Am J Physiol 1994; 267:E306-15.

9. Krief S, Lönnqvist F, Raimbault S, Baude B, Van Spronsen A, Arner P, et al. Tissue distribution of $\beta_{3}$-adrenergic receptor mRNA in man. J Clin Invest 1993;91:344-9.

10. Berkowitz DE, Nardone NA, Smiley RM, Price DT, Kreutter DK, Fremeau RT, et al. Distribution of $\beta_{3}$ adrenoceptor mRNA in human tissues. Eur J Pharmacol 1995;289:223-8.

11. Rodriguez M, Carillon C, Coquerel A, Le Fur G, Ferrara $\mathrm{P}$, Caput D, et al. Evidence for the presence of $\beta_{3}$-adrenergic receptor mRNA in the human brain. Brain Res Mol Brain Res 1995;29:369-75.

12. Gauthier C, Tavernier G, Charpentier F, Langin D, Le Marec $H$. Functional $\beta_{3}$-adrenoceptor in the human heart. J Clin Invest 1996;98:556-62.

13. Chamberlain PD, Jennings KH, Paul F, Cordell J, Berry A, Holmes SD, et al. The tissue distribution of the human $\beta_{3}$-adrenoceptor studied using a monoclonal antibody: direct evidence of the $\beta_{3}$-adrenoceptor in human adipose tissue, atrium and skeletal muscle. Int J Obes Relat Metab Disord 1999;23:1057-65.

14. Lönnqvist F, Krief S, Strosberg AD, Nyberg B, Emorine $\mathrm{LJ}$, Arner P. Evidence for a functional $\beta_{3}$-adrenoceptor in man. Br J Pharmacol 1993;110:929-36.

15. Hoffstedt J, Shimizu M, Sjöstedt S, Lönnqvist F. Determination of $\beta_{3}$-adrenoceptor mediated lipolysis in human fat cells. Obes Res 1995;3:447-57.

16. Enocksson S, Shimizu M, Lönnqvist F, Nordenström J, Arner P. Demonstration of an in vivo functional $\beta_{3}$ adrenoceptor in man. J Clin Invest 1995;95:2239-45.

17. Barbe P, Millet L, Galitzky J, Lafontan M, Berlan M. In situ assessment of the role of the $\beta_{1^{-}}, \beta_{2^{-}}$and $\beta_{3^{-a d r e n o-}}$ ceptors in the control of lipolysis and nutritive blood flow in human subcutaneous adipose tissue. Br J Pharmacol 1996;117:907-13.

18. Tavernier G, Barbe P, Galitzky J, Berlan M, Caput D, Lafontan $M$, et al. Expression of $\beta_{3}$-adrenoceptor with low lipolytic action in human subcutaneous white adipocytes. J Lipid Res 1996;37:87-97.

19. Wheeldon NM, McDevitt DG, Lipworth BJ. Do $\beta_{3-}$ adrenoceptors mediate metabolic responses to isoprenaline. Q J Med 1993;86:595-600. 
20. Blaak EE, Saris WH, van Baak MA. Adrenoceptor subtypes mediating catecholamine-induced thermogenesis in man. Int J Obes Relat Metab Disord 1993;17 Suppl 3:S78-81.

21. Liu YL, Toubro S, Astrup A, Stock MJ. Contribution of $\beta_{3}$-adrenoceptor activation to ephedrine-induced thermogenesis in humans. Int $\mathbf{J}$ Obes Relat Metab Disord 1995; 19:678-85.

22. Schiffelers SL, Blaak EE, Saris WH, van Baak MA. In vivo $\beta_{3}$-adrenergic stimulation of human thermogenesis and lipid use. Clin Pharmacol Ther 2000;67:558-66.

23. Mathvink RJ, Tolman JS, Chitty D, Candelore MR, Cascieri MA, Colwell LF, et al. Discovery of a potent, orally bioavailable $\beta_{3}$ adrenergic receptor agonist, (R)-N-[4-[2-[[2hydroxy-2-(3-piridinyl)ethyl]amino]ethyl]phenyl]-4-[4-[4(trifluoromethyl)phenyl]thiazol-2-yl]benzenesulfonamide. J Med Chem 2000;43:3832-6.

24. Weir JB. New methods for calculating metabolic rate with special reference to protein metabolism. J Physiol 1949;109:1-9.

25. Demacker PN, Hymans AG, Jansen AP. Enzymatic and chemical extraction determinations of free fatty acids in serum compared. Clin Chem 1982;28:1765-8.

26. Li R, Keymeulen B, Gerlo E. Determination of glycerol in plasma by an automated enzymatic spectrophotometric procedure. Clin Chem Lab Med 2001;39:20-4.

27. Wallace AM. Measurement of leptin and leptin binding in the human circulation. Ann Clin Biochem 2000;37:244-52.
28. Smedes F, Kraak JC, Poppe H. Simple and fast solvent extraction system for selective and quantitative isolation of adrenaline, noradrenaline and dopamine from plasma and urine. J Chromatogr 1982;231:25-39.

29. Arch JR, Wilson S. Prospects for $\beta_{3}$-adrenoceptor agonists in the treatment of obesity and diabetes. Int J Obes Relat Metab Disord 1996;20:191-9.

30. Himms-Hagen J, Danforth E. The potential role of $\beta_{3}$-adrenoceptor agonists in the treatment of obesity and diabetes. Curr Opinion Endocrinol Diabetes 1996;3:59-65.

31. Weyer C, Tataranni PA, Snitker S, Danforth E, Ravussin E. Increase in insulin action and fat oxidation after treatment with CL 316,243, a highly selective $\beta_{3}$-adrenoceptor agonist in humans. Diabetes 1998;47:1555-61.

32. Buemann B, Toubro S, Astrup A. Effects of the two $\beta_{3}$-agonists, ZD7114 and ZD2079, on 24-hour energy expenditure and respiratory quotient in obese subjects. Int J Obes Relat Metab Disord 2000;24: 1553-60.

33. Schiffelers SL, Saris WH, van Baak MA. The effect of an increased free fatty acid concentration on thermogenesis and substrate oxidation in obese and lean men. Int $\mathbf{J}$ Obes Relat Metab Disord 2001;25:33-8.

34. Gauthier C, Langin D, Balligand JL. $\beta_{3}$-Adrenoceptors in the cardiovascular system. Trends Pharmacol Sci 2000;21:426-31.

\section{Receive tables of contents by e-mail}

To receive the tables of contents by e-mail, sign up through our Web site at

$$
\text { http://www.mosby.com/cpt }
$$

Choose "E-mail Notification."

Simply type your e-mail address in the box and click the "Subscribe" button.

Alternatively, you may send an e-mail message to majordomo@mosby.com. Leave the subject line blank and type the following as the body of your message:

subscribe cpt_toc

You will receive an e-mail to confirm that you have been added to the mailing list. Note that table of contents e-mails will be sent out when a new issue is posted to the Web site. 